\title{
A Didactic Proposal for EFL in a Public School in Cali
}

\section{Propuesta didáctica para inglés en una escuela pública de Cali*}

\author{
Orlando Chaves \\ orlando.chavez@correounivalle.edu.co \\ Universidad del Valle, Cali, Colombia \\ Alejandro Fernandez \\ alejandro.fernandez.benavides@correounivalle.edu.co \\ Colegio Americano, Cali, Colombia
}

This article reports an action-research project aimed at designing, applying, and assessing a didactic sequence for teaching English as a foreign language in the first grade of a public school in Cali. The article comprises the context, reasons that justified the research, theoretical support, methodology, and results, analyzed through descriptive statistics and a data matrix. The findings suggest that the didactic proposal was easy to use for the teacher, understandable for the students, and appropriate for the students' proficiency level due to its emphasis on the oral skills. It was concluded that didactic material should follow the pacing of the teachers' academic work and has to be closely linked to the reality of teachers and students.

Key words: Didactics, didactic sequence, English as foreign language, primary school.

Este artículo reporta una investigación-acción cuyo objetivo fue el diseño, aplicación y evaluación de una secuencia didáctica para enseñanza de inglés en grado primero de una escuela pública de Cali. Se presentan el contexto, las razones que originaron el estudio, el soporte teórico, la metodología y los resultados obtenidos. Los hallazgos sugieren que la propuesta didáctica fue de fácil uso para la docente, comprensible y acorde con el nivel de proficiencia de los estudiantes, dado su énfasis en las habilidades

* Received: June 17, 2015. Accepted: February 23, 2016.

How to cite this article (APA 6th ed.):

Chaves, O., Fernandez, A. (2016). A didactic proposal for EFL in a public school in Cali. HOW, 23(1), 10-29. http://dx.doi.org/10.19183/how.23.1.139.

This article is licensed under a Creative Commons Attribution-NonCommercial-NoDerivatives 4.0 International License. License Deed can be consulted at http://creativecommons.org/licenses/by-nc-nd/4.0/. 
orales. Se concluyó que un material didáctico en este nivel debe ser acompañado del trabajo académico de los docentes de área y estar ligado a la realidad escolar.

Palabras clave: didáctica, escuela primaria, inglés como lengua extranjera, secuencia didáctica.

\section{Introduction}

Teaching English as a foreign language has increasingly become a priority for the Ministry of National Education in Colombia. This process dates back to Law 115 (Ministerio de Educación Nacional [MEN], 1994), Curricular Guidelines for English Teaching (MEN, 1996), Basic Competence Standards for English (BSCE) (MEN, 2006), and National Plan of Bilingualism (MEN, 2004) with its subsequent variations (PFDCLE in 2010, Colombia Very Well or PNI in 2014 [MEN, 2014], and Colombia Bilingüe in 2015). However, despite the interest of the government in developing the teaching of English, most primary school teachers do not have the proficiency level or the formation in didactics for teaching a foreign language because they are general homeroom (all-subject) teachers, not English teachers per se; they do not have any formation in English or language didactics other than the one they received in secondary school (Cadavid, McNulty, \& Quinchía, 2004; Cárdenas, 2001; Cárdenas, Chaves, \& Hernández, 2015); they have not increased their proficiency or developed their teaching of English because BAs and professional development in this area are offered only for secondary teachers (Bustos \& Chamorro, 2003; Cárdenas et al., 2015; González \& Sierra, 2011). Research has found that the current situation in Colombian public schools does not reflect effective actions aimed at promoting primary school teachers' proficiency (Cárdenas \& Hernández, 2011; González \& Sierra, 2011; MEN, 2014), methodological preparation to teach the foreign language (Cárdenas et al., 2015), or other conditions for English teaching, such as knowledge of appropriate didactic materials (DM) (Miranda \& Echeverry, 2011). The fact that primary school teachers do not have the proficiency level or the formation in didactics is a situation that requires urgent attention (Bastidas \& Muñoz Ibarra, 2011; Cárdenas et al., 2015; González \& Sierra, 2011; de Mejía, 2009).

During the diagnostic stage of this research, information was collected through interviews and surveys from teachers, coordinators, and the principal in a public school. This stage showed that the primary teacher, who is not prepared to teach English, follows a program based on the teaching of isolated words, expressions, and figured pronunciation, the way she learned in her school time. Furthermore, through observation and revision of institutional documents we learned that the amount of time invested for English classes is very poor (one hour per week). The results of the diagnostic stage confirmed other authors' findings about the local and national panorama (Bastidas \& Muñoz Ibarra, 2011; Cárdenas \& Hernández, 2011; Cárdenas et al., 2015; González, 2006; MEN, 2014; Miranda \& Echeverry, 2011). Overall, the problem is indeed instructional, and material implementation that supports a 
more modern view of teaching seems to be required to improve it. Hence, the aim of this research was to provide a public elementary school with a DM (three didactic units) based on a functional-communicative approach to teaching English as a foreign language (EFL) and tailored to the particularities of the context. This paper describes the theoretical support for the design, the application and assessment of the proposal, the methodology followed and the results.

\section{Conceptual Framework}

To understand better the research problem, the theoretical support was divided into two areas: EFL Teaching and Development of Didactic Materials for EFL.

\section{EFL Teaching}

Approach, method, and methodology constitute the basic concepts of EFL didactics and materials development. For Richards and Rodgers (2001), approach is the set of beliefs and theories about language, language learning, and teaching. For these authors, approach, design, and procedure are components of the method. In their proposal, design consists of the model of syllabus, the types of learning and teaching activities, and the learners', teachers', and materials' roles. Richards and Rodgers' tasks, exercises, and procedures are all the classroom actions on the level of implementation or methodology.

In turn, Brown (2007) drew a difference between method and methodology. For him, methods are "specific, identifiable clusters of theoretically compatible classroom techniques" (p. 15), and methodology is "pedagogical practices in general. ... Whatever considerations are involved in 'how to teach' are methodological" (p. 15). From Brown's words, it is inferred that method is the theory related to teaching and methodology is the way teachers do their job in class following certain theoretical positions.

The proposals of Richards and Rodgers (2001), and Brown (2007) share the idea that language teaching is based on the views that teachers have about language and its teaching and learning (approach); then, this approach is set in a series of ordered actions and class processes (method), and finally the method meets the classroom reality through the application of activities, tasks, exercises, and classroom practices that are used every day (techniques). The didactic proposal in this study adopted this idea common to Richards and Rodgers and Brown with the purpose of providing the school with a didactic sequence (DS) supported by some of the most prominent trends within the communicative approach to language teaching: the methods of preview-review, task-based learning, and project-based learning.

Preview-review is an English as a second language (ESL) strategy which applies two teaching stages (preview and review) in order to introduce and practice new topics in the second 
language (L2). The first stage, called preview, introduces the lesson in the first language (L1) and the second teaches it in L2 with a revision of the material in L1 to assure a better content comprehension (Freeman, Freeman, \& Ramirez, 2008; Herrel \& Jordan, 2008).

Task-based learning is an approach aimed at achieving real language appropriacy through contextualized tasks where students must solve problems and situations using language as a communicative vehicle. Here, the task is the focus and language is the tool to reach it. From the assessment that comes from the task outcome, the students receive encouragement to solve problems using language spontaneously and creatively, to focus on real world activities' relationships, and to convey meaning (Nunan, 2004; Willis \& Willis, 2007).

Project-based learning is an ESL learning method that engages students in sustained cooperative learning processes. It emphasizes cooperative learning work aimed at solving situations through inquiring and going deeper into any specific topic by asking questions, debating, predicting, designing plans, collecting information, drawing conclusions, communicating ideas and findings, and creating alternatives (Barron \& Darling-Hammond, 2008; Beckett \& Miller, 2006). This method has two main components, a driving question or problem and a culminating product that responds to the driving question.

These methods were used synchronously by the teacher to complete the main communicative project established at the beginning of the syllabus, which was composed of a limited number of communicative tasks, previewed in L1 and then reviewed in L2 during the application of the DS.

\section{Development of Didactic Materials for $\mathrm{EFL}$}

Curriculum, syllabus, didactic unit, and lesson plan are other concepts supporting the design of DM for EFL. This research adopted the concept of curriculum from the Colombian General Education Law (MEN, 1994):

The set of criteria, study plans, programs, methodologies, and processes that contribute to the integral formation and the construction of cultural, national, regional, and local identity, including the human, academic, and physical resources necessary to put into practice the educative policies and to carry out the institutional education project. (p. 23) ${ }^{1}$

In this definition, curriculum is not only the set of contents, methodologies, and teaching principles and goals, but also the whole educative component that constitutes the academic process.

1 Translation from Spanish by the authors. 
Another concept that shows this close relation between curriculum and its influence on the overall educative practices is Braslavsky's (2005). She linked curriculum to the educational foundations, contents, processes, and outcomes, implying permanent connections between the goals of education and everyday learning experiences, their pacing in relation to the amount of time available for classroom learning experiences, characteristics of teaching institutions in relation to their methods, resources for learning and teaching, evaluation, and teachers' profiles.

Braslavsky (2005) centers her concept on the relationship of educative philosophy, contents, and sequence of the study plans with the particular contexts where the pedagogical practices are carried out, all of them in service of a specific approach and method to be adopted in the teaching process.

The difference between Braslavsky's (2005) concept and the one in the Colombian General Education Law (MEN, 1994) is that the former creates or establishes distance regarding the relation between education and cultural identity, and does not list the resources that may comprise a curriculum (human, academic, and material). The concept of the Colombian General Education Law lists these elements and considers them to be important to develop the national identity. Thus, this research fostered the definition of the Ministry of National Education for its breadth and elements related to the development of the educative process. In the design proposed here, syllabus, didactic unit, and lesson plan are understood as elements of the curriculum, the syllabus containing didactic units and these comprising lesson plans.

In turn, syllabus is the process of specifying and ordering the contents of a course, which follows the curriculum that involves the philosophy, purposes, design, and implementation of the entire educative program (Graves, 1996). For White (1988), syllabus refers to the contents or topics that define the curriculum. Dubin and Olshtain (1997) propose that syllabus is a common place where the curriculum philosophy has the chance to move into more detail in a progressive way, arriving at the specific objectives on the operational levels of teaching.

Graves (1996), White (1988), and Dubin and Olshtain (1997) share the conception of the syllabus as the ordered way teachers present their course contents following a precise methodological approach in terms of detailed objectives and class activities. In other words, syllabus is the second step in the progression of developing DM, curriculum being the first. Syllabus materializes the how-to-do, and how-to-carry-out a particular perspective about language education.

Third in the scale of development of DM for EFL is the concept of the didactic unit. The didactic unit is the set of teaching and learning units of a syllabus, every single topic that develops a same content (Matencio, 2009). For Antúnez (1993), a didactic unit is the 
intervention of all the elements that affect the teaching-learning process with an inner methodological coherence and a determined period.

A didactic unit organizes the processes of language learning and provides teachers with a tool to guide their methodology and to focus their efforts on an aim towards a feasible and measurable goal in a clear frame of time (Antúnez, 1993; Matencio, 2009). This is the perspective here adopted for didactic unit: the set of inner time-and-content divisions of a syllabus, which point at a precise teaching objective and help to make real what teachers have in mind to teach.

The last concept supporting the design of the DS is lesson plan. Bailey and Nunan (1996) compare a lesson plan to a map where teachers describe what they expect from a lesson. A lesson is understood in this article as a unit of instruction shorter than a didactic or thematic unit, a small thematic/didactic unit corresponding to a short period of time-usually one or two hours - in which one single lesson or class occurs. This lesson plan is commonly composed of elements that can be controlled by the teacher; they include the content and sequence of information to be developed, the frequency and time for the activities, the materials to be used, and, most important, the students' quality and quantity of participation, especially in the case of a student-centered curriculum.

This research assumed the concept of lesson plan as the DM design element closest to the class reality. A lesson plan embeds the class activities and what teachers plan to do with their students following a brief, one-single-session unit. Lesson plans go framed within a syllabus, which is part of a curriculum that guides the general academic process. While the curriculum belongs to the general realm of the educational philosophy, and the syllabus fits into the particular sphere of the institutional educational organization, the lesson plan is the teacher's materialization of what he or she thinks about what to teach, how to teach, and when to teach. A lesson plan gives the order and the aim to keep in every class or lesson.

In sum, this proposal was supported by theoretical categories which work in function of two major aspects: didactics of EFL teaching, and EFL materials development.

\section{Method}

This was an action-research study conceived as a process that applies the acquired knowledge to supply a community's needs or to act in a positive way in the context where the academic experience takes place (Carr \& Kemmis, 1986). Here, an academic proposal was designed purporting to supply the need of a DS for EFL in a public school. Although the researchers did not have control over the course, they could gain access to it thanks to the teacher. The whole process consisted of one application cycle; a DS comprised of three units was designed and then applied and evaluated. A data matrix — a table with rows representing 
the units of analysis and columns representing categories in the research questions (Miles \& Huberman, 1994) — was used as a qualitative analysis tool.

\section{Context}

This research took place in a public school located in Cali, Colombia, which offers preschool and elementary education. Each grade has 35-40 students. Though the school has rather good facilities, the Institutional Educational Project (IEP) has no guidelines regarding the teaching of a foreign language. It includes no explicit view of language in general, foreign language in particular, its learning and teaching, or any methodological guidelines to do it. The material proposed aimed at supporting curricular decisions, as the IEP missed guidelines for the institution and the "one-person English department" had not yet created a proposal for foreign language teaching and learning at the elementary level.

English in this school is a subject within the area of humanities, comprising Spanish and English. The faculty are six teachers, all of them with a BA and more than six years' experience. Each teacher is in charge of a group as homeroom teacher and teaches all the subjects in the curriculum. No teacher follows a schoolbook for English. Only one teacher has EFL formation. During the research, she was in charge of the first grade in the afternoon shift. The other teachers in the subsequent grades do not continue her job in the foreign language because they lack EFL training. The only teacher that participated in the study was the one that holds a BA in EFL. She has worked in that school since 2011 teaching all the basic subjects. Her 36 first-grade children (20 girls and 16 boys, aged five to eight) also participated in the study. This group (afternoon shift) was observed over three months. Like the rest of the groups, this class received two 45-minute classes of English per week.

\section{Stages}

This action research comprised three stages and was carried out over a year and a half.

The diagnosis stage (eight months) comprised:

- the initial contact with the institution,

- the consent to carry out the research,

- a general approach to the institution (to establish the needs related to the research problem),

- interview with the first grade teacher,

- school syllabus analysis, and

- diagnosis of the students' English level (during four sessions with the guide and participation of the teacher). 
During the design stage (seven months), a DS consisting of three didactic units was designed. In light of some theoretical approaches in language didactics and second language acquisition (SLA), the DM was developed taking into account the learners' and teacher's needs, observations, talks with the teacher and the students, and journaling.

During the application stage (three months) continuous evaluation was done through observation and journaling of the experiences in the classroom. Evaluation led to continuous readjustment of the proposal. To evaluate the application of the proposal, the researchers collected information regarding the students' advances, their performance in the activities and workshops, and the impact of the didactic elements used in the lessons. Then, a test (oral and written comprehension and oral production) was applied. The results were analyzed in terms of the impact of the proposal on the students' learning. Table 1 summarizes the research stages and the data collection instruments.

Table 1. Data Collection Techniques and Instruments

\begin{tabular}{|c|c|c|}
\hline Stage & Technique & Instrument \\
\hline \multirow{2}{*}{ Stage 1} & Structured interview & Questionnaire \\
\hline & Informal interview & Conversation with the teacher \\
\hline \multirow[t]{2}{*}{ Stage 2} & Theoretical revision & $\begin{array}{l}\text { Results of the first diagnosis } \\
\text { Observation } \\
\text { Journaling } \\
\text { Interviews with the teacher }\end{array}$ \\
\hline & Selection of didactic material & $\begin{array}{l}\text { Observation } \\
\text { Journaling } \\
\text { Talks with the student }\end{array}$ \\
\hline \multirow{3}{*}{ Stage 3} & Application & $\begin{array}{l}\text { Observation } \\
\text { Journaling }\end{array}$ \\
\hline & Evaluation & $\begin{array}{l}\text { Observation } \\
\text { Journaling } \\
\text { Revision of the application workshops with } \\
\text { the teacher }\end{array}$ \\
\hline & Redesign & $\begin{array}{l}\text { Observation } \\
\text { Journaling }\end{array}$ \\
\hline
\end{tabular}




\section{Proposal of Didactic Sequence}

The DS offered as a result of this research in a public school in Cali was designed on the bases of the Common European Framework of Reference for Languages (Council of Europe, 2001), the current Colombian foreign language education policies, and some of the most relevant aspects of the communicative approach: task-based instruction, project-based learning, and preview-review methods. The DS consisted of three fundamental stages to teach EFL to beginners: input, activities, and interaction. These units used the oral skills as the main learning element because the kids who participated in the research were just beginning their process of reading and writing in their L1. The structure of the lessons comprised three stages:

First, the students received input (examples and explanations) about the use of some communicative functions in their daily life; then, songs were used to follow the topics, communicative functions, vocabulary, and structures and recall the students' background knowledge. The songs were complemented with dynamic activities of speaking in which the students had to interact using the structures and the key elements studied in class.

Second, listening activities, total physical response (TPR) exercises, and oral examples with visual aids such as flashcards and memory cards were used. This stage began with the implementation of activities related to the new vocabulary and it was then applied in communicative situations through role plays. After that, the teacher told a story and invited the students to comment and answer questions about what they had just listened. In addition, role play and speaking exercises were carried out.

During the third part of the lesson, didactic games were used as a ludic way to improve the input the students had just received; also, to reinforce it, they interacted in communicative situations to get the necessary functions, expressions, vocabulary, and pronunciation according to their level. There was an application workshop at the end of each lesson.

The units dealt with communicative situations that offered the opportunity to study the topics in terms of communicative competences, structures, and vocabulary to be worked through songs, examples, oral exercises, and application workshops in class. This article includes only the first didactic unit to illustrate the research (Table 2 summarizes it). 
Table 2. Didactic Unit 1: My School Life

\begin{tabular}{|c|c|c|c|c|c|c|}
\hline \multicolumn{7}{|c|}{ Unit 1: My School Life (8-12 hours) } \\
\hline & Contents & Tasks & Project & $\begin{array}{c}\text { Preview- } \\
\text { review }\end{array}$ & Resources & Evaluation \\
\hline $\begin{array}{l}\text { Topic 1: } \\
\text { Introduce } \\
\text { yourself! }\end{array}$ & $\begin{array}{l}\text { Linguistics: } \\
\text { Vocabulary } \\
\text { (personal } \\
\text { pronouns) } \\
\text { Structures: Verb } \\
\text { to be (I am, she } \\
\text { is, he is, you are) } \\
\text { Functions: } \\
\text { Introduce } \\
\text { him/herself, to } \\
\text { use greetings and } \\
\text { to know }\end{array}$ & $\begin{array}{l}\text { Songs, role } \\
\text { plays, oral } \\
\text { drills, } \\
\text { physical } \\
\text { exercises, } \\
\text { handicraft } \\
\text { tasks, oral } \\
\text { games, and } \\
\text { written } \\
\text { activities. }\end{array}$ & $\begin{array}{l}\text { The world } \\
\text { around me. } \\
\text { (The } \\
\text { students } \\
\text { prepared an } \\
\text { oral } \\
\text { presentation } \\
\text { introducing } \\
\text { themselves } \\
\text { and some } \\
\text { classmates). }\end{array}$ & $\begin{array}{l}\text { Review in L2 } \\
\text { of contents } \\
\text { from social } \\
\text { studies and } \\
\text { Spanish } \\
\text { taught } \\
\text { previously in } \\
\text { L1. }\end{array}$ & $\begin{array}{l}\text { The } \\
\text { Greetings } \\
\text { Song, } \\
\text { Flashcards, } \\
\text { application } \\
\text { workshop. }\end{array}$ & $\begin{array}{l}\text { Mid-term } \\
\text { with two } \\
\text { components: } \\
\text { oral and } \\
\text { written } \\
\text { (written } \\
\text { workshop } \\
\text { and role } \\
\text { play). }\end{array}$ \\
\hline $\begin{array}{l}\text { Topic 2: } \\
\text { My school } \\
\text { supplies }\end{array}$ & $\begin{array}{l}\text { Linguistic: } \\
\text { Vocabulary } \\
\text { (school supplies) } \\
\text { Expressions: I } \\
\text { like, I do not like. } \\
\text { Structures: } \\
\text { personal } \\
\text { pronouns, } \\
\text { possessive } \\
\text { pronouns, verb } \\
\text { to be (it is), } \\
\text { demonstrative } \\
\text { adjectives (this is, } \\
\text { that is). } \\
\text { Expression (my } \\
\text { pencil, sharpener, } \\
\text { eraser, etc., is } \\
\text { yellow, blue, } \\
\text { etc.), colors. } \\
\text { Functions: to ask } \\
\text { an object, a favor } \\
\text { and to grant it. }\end{array}$ & $\begin{array}{l}\text { Short review } \\
\text { of the } \\
\text { previous } \\
\text { topic, visual } \\
\text { activities, } \\
\text { role plays, } \\
\text { oral drills, } \\
\text { games as } \\
\text { bingo, } \\
\text { puzzles, } \\
\text { lotto, and } \\
\text { application } \\
\text { workshop. }\end{array}$ & $\begin{array}{l}\text { This is my } \\
\text { pencil case! } \\
\text { (In groups, } \\
\text { the students } \\
\text { prepared } \\
\text { chart } \\
\text { presentation } \\
\text { s informing } \\
\text { about and } \\
\text { describing } \\
\text { their school } \\
\text { supplies) }\end{array}$ & $\begin{array}{l}\text { Review in L2 } \\
\text { of contents } \\
\text { from social } \\
\text { studies and } \\
\text { math taught } \\
\text { previously in } \\
\text { L1. }\end{array}$ & $\begin{array}{l}\text { Flashcards, } \\
\text { school } \\
\text { supplies, } \\
\text { memory } \\
\text { cards, and } \\
\text { an } \\
\text { application } \\
\text { workshop. }\end{array}$ & $\begin{array}{l}\text { Mid-term } \\
\text { with two } \\
\text { components: } \\
\text { oral and } \\
\text { written } \\
\text { (written } \\
\text { workshop } \\
\text { and } \\
\text { role-play). }\end{array}$ \\
\hline
\end{tabular}




\begin{tabular}{|c|c|c|c|c|c|c|}
\hline \multicolumn{7}{|c|}{ Unit 1: My School Life (8-12 hours) } \\
\hline & Contents & Tasks & Project & $\begin{array}{c}\text { Preview- } \\
\text { review }\end{array}$ & Resources & Evaluation \\
\hline $\begin{array}{l}\text { Topic 3: } \\
\text { What is } \\
\text { your } \\
\text { classroom } \\
\text { like? }\end{array}$ & $\begin{array}{l}\text { Linguistic: } \\
\text { Adjectives. } \\
\text { Structures: (like, } \\
\text { don't like), } \\
\text { personal } \\
\text { pronouns, } \\
\text { possessive } \\
\text { pronouns, verb } \\
\text { to be (it is), } \\
\text { demonstrative } \\
\text { adjectives (this is, } \\
\text { that is) } \\
\text { Expression (my } \\
\text { pencil, sharpener, } \\
\text { eraser, etc., is } \\
\text { yellow, blue, etc.) }\end{array}$ & $\begin{array}{l}\text { Short } \\
\text { review, song, } \\
\text { oral drills, } \\
\text { role plays, } \\
\text { board games } \\
\text { as lotto and } \\
\text { puzzles, and } \\
\text { an } \\
\text { application } \\
\text { workshop. }\end{array}$ & $\begin{array}{l}\text { I study here! } \\
\text { (The } \\
\text { students } \\
\text { prepared a } \\
\text { presentation } \\
\text { describing } \\
\text { their } \\
\text { classroom: } \\
\text { they made a } \\
\text { map and } \\
\text { then } \\
\text { presented it } \\
\text { to other } \\
\text { classes). }\end{array}$ & $\begin{array}{l}\text { Review in L2 } \\
\text { of contents } \\
\text { from } \\
\text { Spanish } \\
\text { taught } \\
\text { previously in } \\
\text { L1. }\end{array}$ & $\begin{array}{l}\text { The } \\
\text { Rainbow } \\
\text { Colors } \\
\text { Song, } \\
\text { flashcards, } \\
\text { school } \\
\text { supplies, } \\
\text { memory } \\
\text { cards, and } \\
\text { an } \\
\text { application } \\
\text { workshop. }\end{array}$ & $\begin{array}{l}\text { Mid-term } \\
\text { with two } \\
\text { components: } \\
\text { oral and } \\
\text { written } \\
\text { (written } \\
\text { workshop } \\
\text { and a } \\
\text { role-play). }\end{array}$ \\
\hline
\end{tabular}

After having described the modus operandi of the proposal through the first didactic unit, readers will find that the next section explores the results of the application of the whole DS.

\section{Results}

The results were studied in terms of the pedagogical view of the teacher, the use of the DM, and the students' performance at the end of the experience. The evaluation was a process of permanent revision and re-design.

\section{Pedagogical View}

According to the participants, the use of the DS played a relevant role in the learning process. The results showed that the didactic units were comprehensible and could be completed in the class time. This allowed the students to do their activities and to reflect with the teacher's help on their own context out of the school. The teacher expressed it this way:

During my classes, I try to make the students feel comfortable with what they do and to understand the importance of what they learn. To do this, it is necessary to take into account both, the language level to be taught and the students' context. (Informal talk) ${ }^{2}$

2 The excerpts have been translated from Spanish. 
A student reported why he liked the workshops:

I liked the workshops because they had beautiful pictures and I could color them. (Student 14, Research journal)

Furthermore, the teacher stated that she noticed an increase in the students' interest for her English classes linked to the use of relevant topics for them. During the application of the DS, the teacher constantly highlighted, in conversations with the researchers, the importance of using daily life examples and notions familiar to the students' lives to engage them. In her words:

From this perspective, I consider that the application of this proposal has allowed the students to become more engaged in the class because we discussed about topics of their daily life.

Students also reported an increased relevance:

I remember better the words when I see pictures and when teacher A, explains me with songs how to talk to my dad and grandma. (Student 21, Research journal)

Finally, the teacher acknowledged the facility to use, comprehend, and apply the material taken to the class to achieve an improvement in the students' process. This was congruent with the necessary characteristics for an effective DM: ease of use, possibility of control, individual or collective possibility of use, versatility, possible modification during the academic process, promotion of another DM, and richness of activities that can fulfill the students' learning process and completeness of the information they can offer $(\mathrm{C} . \mathrm{H}$. Guerrero, 2008). The teacher stated:

In sum, I noticed that the designed material by the researchers was in line with the course syllabus, and was both, of easy application in the classroom and of easy understanding for the students. Moreover, we could supplement this didactic proposal with the use of other material such as bingos, puzzles, and lotteries to strengthen the contents and the proposed activities were useful both for individual work as for group work.

In conclusion, the teacher judged the researchers' intervention and the DM designed by them as positive because the proposal took into consideration the context and its relation with notions familiar to the students. Additionally, students reported an increased interest and relevance of the topics and activities.

Regarding the syllabus proposed by the researchers, the teacher underlined that the thematic order was suitable because it allowed important cross-curricular links with life and social sciences and let the students practice the previous lessons in those subjects. She also stated that the design of the material given for the activities was clear and of easy management in the classroom. Likewise, the activities helped the students to develop oral skills because, at the end, most of them were able to express simple ideas in the foreign language. Finally, the teacher emphasized that the evaluation method worked based on clear evaluation criteria, let 
her have a clearer idea about the students' English level and helped her to update her pedagogic views in function of what her students thought and the way they should be taught.

\section{Use of the Didactic Material}

The DS was evaluated in terms of students' comprehension, time required by them to develop the activities, and the final results of the activities of every application workshop. Regarding comprehension, during the application "most of the students were able to understand every class task." 3 During the classes, the students had full accompaniment of the researchers and the teacher in order to answer possible questions and to help when necessary. For instance, some students stated that they could understand the given material due to the pictures in it and the examples given in the workshops. As a sample of it, here is one of those statements: "For me, it was easy to see the picture and the meaning and what I had to do was clear for the pretty drawings" (Student 2, Journal).

In general, the results showed that most of the students $(66 \%)$ were able to understand immediately or with the first explanation the activities they had to develop in the application stages. On the other hand, during all the application period, 33\% of the students had problems trying to understand or did not understand at all what they had to do with the material given and had to ask for explanation several times, or they simply repeated what their classmates did. Table 3 shows the students' comprehension level of the didactic units. The numbers show that there was a clear decrease of students who needed several explanations while the ones who understood without any further explanation increased. The majority of students understood with only one explanation. In other words, their comprehension increased through time and although the increase of comprehension was not that big, the decrease of students who needed several explanations was important.

From the average, it is possible to state that, in general terms, the given material was understandable for the students. However, nearly 33\% (8 plus 2.5) had difficulties understanding the explanations. The total numbers vary according to attendance in every session.

Regarding the time the students invested in the application workshops in each session, the information is very similar to that above. Most students could finish the application workshops during the class, others had to finish them at home, and a reduced number did not finish them at all. Table 4 shows the time students invested in finishing the application workshops.

3 Teacher's statement. 
Table 3. Ease of Use of the Didactic Sequence

\begin{tabular}{|c|c|c|c|c|c|}
\hline Week & $\begin{array}{c}\text { Students who } \\
\text { understood } \\
\text { immediately }\end{array}$ & $\begin{array}{l}\text { Students who } \\
\text { understood } \\
\text { with only one } \\
\text { explanation }\end{array}$ & $\begin{array}{c}\text { Students who } \\
\text { understood } \\
\text { with several } \\
\text { explanations }\end{array}$ & $\begin{array}{l}\text { Students who } \\
\text { did not } \\
\text { understand }\end{array}$ & Attendance \\
\hline 1 & 5 & 17 & 6 & 3 & 31 \\
\hline 2 & 5 & 11 & 12 & 4 & 32 \\
\hline 3 & 4 & 15 & 5 & 6 & 30 \\
\hline 4 & 6 & 13 & 11 & 2 & 32 \\
\hline 5 & 3 & 16 & 8 & 5 & 32 \\
\hline 6 & 3 & 16 & 6 & 3 & 30 \\
\hline 7 & 5 & 17 & 8 & 1 & 31 \\
\hline 8 & 7 & 15 & 4 & 4 & 30 \\
\hline Average & 6 & 17 & 8 & 2.5 & \\
\hline
\end{tabular}

Table 4. Time Invested by Students in Finishing the Application Workshops

\begin{tabular}{|c|c|c|c|c||}
\hline Week & $\begin{array}{c}\text { Students who } \\
\text { finished in class }\end{array}$ & $\begin{array}{c}\text { Students who } \\
\text { finished at home }\end{array}$ & $\begin{array}{c}\text { Students who did } \\
\text { not finish }\end{array}$ & Attendance \\
\hline 1 & 15 & 11 & 5 & 31 \\
\hline 2 & 18 & 12 & 2 & 32 \\
\hline 3 & 20 & 4 & 6 & 30 \\
\hline 4 & 22 & 4 & 4 & 32 \\
\hline 5 & 15 & 13 & 5 & 32 \\
\hline 6 & 19 & 6 & 7 & 31 \\
\hline 7 & 24 & 0 & 3 & 30 \\
\hline 8 & 26 & 1 & $\mathbf{5}$ & \\
\hline Average & $\mathbf{2 0}$ & $\mathbf{6}$ & & \\
\hline
\end{tabular}


From the previous information, most students (62.5\%) finished the application workshops within the session time. The group that finished at home decreased progressively, from 11 to 1 , except in week 5 , when students had time constraints due to an institutional activity, an emergency drill. A few students (15.6\%) did not finish the activities at home. The students who took their work home possibly did not have enough help at home. This might be linked to the parents' low English level, as asserted by the teacher during one of the informal conversations with the researchers.

The analysis of materials' appropriateness was based on the results of the written workshops. At this stage, the DM was evaluated as a comprehensible element for the students. The students were able to understand and develop correctly the activities; the DM was at their linguistic level (A. Guerrero, 2009). The materials' appropriateness was observed during the application when some students were able to develop some exercises by themselves. For instance, Student 19 said: "I feel good when I see the worksheets; I think I can develop them without the teacher because they are what we have just studied in class" (Journal).

After having evaluated the activities, tasks, and exercises during the application stage, the three task completion categories emerged: students who developed the activities completely, students who did it partially, and the ones who did not accomplish them. Table 5 shows this.

Table 5. Task Completion

\begin{tabular}{|c|c|c|c|c||}
\hline Week & $\begin{array}{c}\text { Students who } \\
\text { finished the } \\
\text { activities completely }\end{array}$ & $\begin{array}{c}\text { Students who } \\
\text { finished the } \\
\text { activities partially }\end{array}$ & $\begin{array}{c}\text { Students who did } \\
\text { not finish the } \\
\text { activities }\end{array}$ & Attendance \\
\hline 1 & 15 & 12 & 4 & 31 \\
\hline 2 & 12 & 16 & 4 & 32 \\
\hline 3 & 20 & 4 & 6 & 30 \\
\hline 4 & 22 & 7 & 3 & 32 \\
\hline 5 & 12 & 6 & 4 & 32 \\
\hline 6 & 19 & 7 & 3 & 31 \\
\hline 7 & 18 & 10 & 1 & 30 \\
\hline 8 & 21 & 8 & 4 & \\
\hline Average & 1 & 9 & & 30 \\
\hline
\end{tabular}


As the results show, most students could finish the activities of every class in the established time, or in some cases at home. From the total of students by session, 13\% (four students in average) could not develop the activities completely and therefore, their performance was not as expected. These results suggest that the DM designed was at the appropriate level for the students, as most of them finished their exercises correctly. Anyway, task completion also depends on other factors like students' attention and previous knowledge, among others.

To sum up, the results demonstrated that the proposed DM accomplished its purpose by fulfilling the design requisites because the activities were comprehensible, they could be totally developed during the classes, and they were also at the level of the students' linguistic and cognitive development. As proof, most of the students accomplished the workshops understanding what they were asked to do, they also did it in the time established by the teacher, and they developed the exercises correctly. It was also evidenced that the students did their work with enthusiasm and interest, showing curiosity during all the activities and questioning constantly. In this aspect, the most important element was the development and use of the foreign language outside the classroom.

\section{Students' Final Performance}

The results of the final evaluation are presented following the BSCE (MEN, 2006), which state that the cognitive mastery in a foreign language is defined by the progressive acquisition of three kinds of competence: linguistic, pragmatic, and sociolinguistic (Canale \& Swain, 1980).

The students' performance was evaluated with a special focus on the oral skills in class in level A1 through constant observation of the students' process and a final exam. The results shown in Table 6 were taken at the end of the application of the DS, through questions and observation in class, and a journal in the process. During the final exam interview, the teacher asked the students questions about their lives and families and the most important topics of the DS. To help the students, the teacher repeated the questions, gestured, mimicked, and spoke slowly and clearly. Table 6 shows the results of the oral test.

In regard to listening, most students were able to understand what the teacher asked and what she told them to do. However, a third of the group could not understand two of the three types of questions. The difficulty was making the students understand the instructions so they could cope with communicative situations.

Concerning speaking, the students showed improvement similar to the one in listening. Two thirds reached the achievements and answered adequately the questions they were asked; just a third had trouble doing so because they did not answer or say something coherent with the question. The results suggest that the aim of these didactic units was accomplished for most of the students and that oral skills must be strengthened further. For 
those who presented difficulties, the teacher recommended some special extra work in class and homework to develop in order to engage the students and their parents.

Table 6. Results of the Final Exam

\begin{tabular}{||l|c|c|c||}
\hline \multicolumn{1}{|c|}{ Listening } & $\begin{array}{c}\text { Reached } \\
\text { the goal }\end{array}$ & $\begin{array}{c}\text { Did not reach the } \\
\text { goal }\end{array}$ & Total \\
\hline $\begin{array}{l}\text { I understand when I am greeted and } \\
\text { someone says goodbye to me. }\end{array}$ & 29 & 1 & 30 \\
\hline $\begin{array}{l}\text { I follow instructions related to my class } \\
\text { activities and ludic activities proposed by } \\
\text { my teacher. }\end{array}$ & 19 & 11 & 30 \\
\hline $\begin{array}{l}\text { I understand simple questions about } \\
\text { myself, my family, and my surroundings. }\end{array}$ & 21 & 9 & 30 \\
\hline $\begin{array}{l}\text { Speaking } \\
\text { I respond to greetings and farewells. }\end{array}$ & Reached the goal & $\begin{array}{c}\text { Did not } \\
\text { reach the goal }\end{array}$ & Total \\
\hline \begin{tabular}{l} 
I answer the question: How are you? \\
\hline $\begin{array}{l}\text { I answer questions about people, objects, } \\
\text { and places of my surroundings. }\end{array}$
\end{tabular}$\quad 28$ & 2 & 30 \\
\hline
\end{tabular}

All in all, it is possible to avow that the results were positive in terms of the teacher's opinion of the DS, the comprehensibility of the didactic units for the students, and the suitability of the activities for the students' level. The students' performance in the oral skills (listening-speaking) was good, although this area still needs more adjustment.

\section{Conclusions}

This study yielded a series of conclusions divided into three main axes corresponding to its objectives: pedagogical impact on the teacher and her students, assessment of the DM, and students' performance.

First, the pedagogical impact that this proposal had on the teacher and her students can be seen in what they stated about the experience. The teacher supplemented her materials, reinforced the school curricular bases for EFL, and recognized the need of aligning the teaching to the particular social and pedagogical conditions of the group. The students 
reported increased comprehension and interest, corroborated by the time they took to advance and their accurate development of the activities.

Second, it was reaffirmed that, to be effective, curriculum and materials development must take into consideration the particularities of the specific learning and teaching situations, like the linguistic and communicative development of the students, their ease to be understood-written material, instructions, and activities - controllability by the teacher, possibility of collective or individual usage, adaptability to the context, openness to modification, and promotion of intertextual work with other DM (A. Guerrero, 2009). Additionally, the students' performance was improved: their oral skills bettered and the final assessment showed that most students reached the objectives sought.

In conclusion, this proposal fulfilled its purposes and was useful for the public school where it was carried out, supplying a DS to teach EFL in a first grade and providing curricular guidelines with pedagogic and didactic bases that can be extrapolated to other grades. It had a positive impact on students_ — as a tool to learn English—and on their teacher_ — as a help to teach according to current linguistics policies and EFL didactic trends - which allowed them to use the communicative approach to teaching language.

Finally, it is necessary to acknowledge some limitations of this study. The causes of the failure of some students in the application of the proposal need to be traced further. Three major causes are hypothesized in connection to failure: lack of help at home with their school activities, poor time-on-task at school, and lack of contact with the target language outside of the school. These factors contribute to a negative result in the students' general academic performance. Furthermore, the relations among ease of use, time invested, and task completion remain to be studied.

\section{References}

Antúnez, S. (1993). Claves para la organización de centros escolares [Clues for the organization of school centers]. Barcelona, ES: Editorial ICE-Horsori.

Bailey, K. M., \& Nunan, D. (Eds.). (1996). Voices from the language classroom. Cambridge, UK: Cambridge University Press.

Barron, B., \& Darling-Hammond, L. (2008). Teaching for meaningful learning: A review of research on inquiry-based and cooperative learning. San Francisco, CA: Jossey-Bass.

Bastidas, J. A., \& Muñoz Ibarra, G. (2011). A diagnosis of English language teaching in public elementary schools in Pasto, Colombia. HOW, 18(1), 95-111.

Beckett, G. H., \& Miller, P. C. (Eds.). (2006). Project-based second and foreign language education: Past, present, and future. Greenwich, CT: Information Age.

Braslavsky, C. (2005). A new stage in the IBE's capacity-building activities: Moving forward on the community of practice and networked communication in curriculum development. Educational Innovation and Information, 119-120, 2-10. 
Brown, H. D. (2007). Teaching by principles: An interactive approach to language pedagogy. New York, NY: Pearson Education.

Bustos, M. E., \& Chamorro, L. P. (2003). Capacitación y actualización docente de profesores de inglés en escuelas públicas de la ciudad de Pasto [Teachers' profesional development in public schools in Pasto] (Unpublished undergraduate monograph). Universidad de Nariño, Pasto.

Cadavid, C., McNulty, M., \& Quinchía, D. (2004). Elementary English language instruction: Colombian teachers' classroom practices. PROFILE Issues in Teachers' Professional Development, 5(1), 37-55.

Canale, M., \& Swain, M. (1980). Theoretical bases of communicative approaches to second languages teaching and testing. Applied Linguistics, 1, 12-26.

Cárdenas, R. (2001). Teaching English in primary: Are we ready for it? HOW, 8(1), 1-8.

Cárdenas, R., \& Hernández, F. (2011). Towards the formulation of a proposal for opportunity-to-learn standards in EFL learning and teaching. Íkala, Revista de Lenguaje y Cultura, 16(28), 231-258.

Cárdenas, R., Chaves, O., \& Hernández, F. (2015). Implementación del Programa Nacional de Bilingüismo en Cali - Colombia: Perfiles de los docentes de inglés [Implementation of the National Bilingual Program in Cali - Colombia: Profiles of the teachers of English]. Cali, CO: Editorial Universidad del Valle.

Carr, W., \& Kemmis, S. (1986). Becoming critical: Education, knowledge, and action research. London, UK: Falmer Press.

Council of Europe. (2001). Common European framework of reference for languages: Learning, teaching, assessment. Cambridge, UK: Cambridge University Press.

de Mejía, A. M. (2009). Teaching English to young learners in Colombia. MEXTESOL, 33(1), 103-114.

Dubin, F., \& Olshtain, E. (1997). Course design: Developing programs and materials for language learning. Cambridge, UK: Cambridge University Press.

Freeman, Y. S., Freeman, D. E., \& Ramirez, R. (Eds.). (2008). Diverse learners in the mainstream classroom. Portsmouth, NH: Heinemann.

González, A. (2006). On materials use training in EFL teacher education: Some reflections. PROFILE Issues in Teachers' Professional Development, 7(1), 101-115.

González, A., \& Sierra, A. M. (2011, October). Challenges and opportunities for public elementary school teachers in the National Program of Bilingualism. Paper presented at the 46th ASOCOPI Annual Conference, Bogotá, Colombia.

Graves, K. (Ed.). (1996). Teachers as course developers. Cambridge, UK: Cambridge University Press. http://dx.doi.org/10.1017/CBO9780511551178.

Guerrero, A. (2009). Los materiales didácticos en el aula [Didactic materials in the classroom]. Temas para la Educación, 5, 30-36.

Guerrero, C. H. (2008). Bilingual Colombia: What does it mean to be bilingual within the framework of the National Plan of Bilingualism? PROFILE Issues in Professional Development, 10(1), 27-45. 
Herrel, A. L., \& Jordan, M. L. (2008). 50 strategies for teaching English language learners. Upper Saddle River, NJ: Pearson Education.

Matencio, R. (2009). La unidad didáctica en educación primaria [The didactic unit in primary education]. Córdoba, AR: Centro de Profesorado.

Miles, M. B., \& Huberman, A. M. (1994). Qualitative data analysis: An expanded sourcebook. Thousand Oaks, CA: Sage Publications.

Ministerio de Educación Nacional, MEN. (1994). Ley general de educación [Colombian general law of education]. Bogotá, CO: Author.

Ministerio de Educación Nacional, MEN. (1996). Lineamientos curriculares idiomas extranjeros [Curricular guidelines for the teaching of foreign languages]. Bogotá, CO: Author.

Ministerio de Educación Nacional, MEN. (2004). Plan Nacional de Bilingüismo [National Bilingual Plan]. Bogotá, CO: Author.

Ministerio de Educación Nacional, MEN. (2006). Estándares básicos de competencias en lenguas extranjeras: inglés [Basic standards for foreign languages: English]. Bogotá, CO: Author.

Ministerio de Educación Nacional, MEN. (2014). Programa nacional de inglés 2015-2025: documento de socialización [National Program of English 2014-2025: Socialization document]. Retrieved from http://www.colombiaaprende.edu.co/html/micrositios/1752/articles-343287_ recurso_1.pdf.

Miranda, N., \& Echeverry, A. (2011). La gestión escolar en la implementación del Programa Nacional de Bilingüismo en instituciones privadas de Cali [School administration in the implementation of the bilingual Colombia program in private educational institutions in Cali]. Íkala, Revista de Lenguaje y Cultura, 16(29), 67-125.

Nunan, D. (2004). Task-based language teaching. Cambridge, UK: Cambridge University Press. http://dx.doi.org/10.1017/CBO9780511667336.

Richards, J. C., \& Rodgers, T. S. (2001). Approaches and methods in language teaching. Cambridge, UK: Cambridge University Press. http://dx.doi.org/10.1017/CBO9780511667305.

White, R. V. (1988). The ELT curriculum: Design, innovation and management. Oxford, UK: Blackwell. Willis, D., \& Willis, J. (2007). Doing task-based teaching. Oxford, UK: Oxford University Press.

\section{The Authors}

Orlando Chaves holds a BA in Philology and Languages (Universidad Nacional de Colombia), an MA in Linguistics, (Universidad del Valle), and an MA in English Teaching (Universidad de Caldas). He is a teacher at Universidad del Valle and a member of the EILA research group.

Alejandro Fernandez holds a BA in Foreign Languages (Universidad del Valle), a C2 DALF certification, and a C1 MET certification. He is an English teacher at Colegio Americano de Cali and a member of EILA research group. Currently, he is enrolled in the MA in Intercultural and Interlinguistic Studies (Universidad del Valle). 